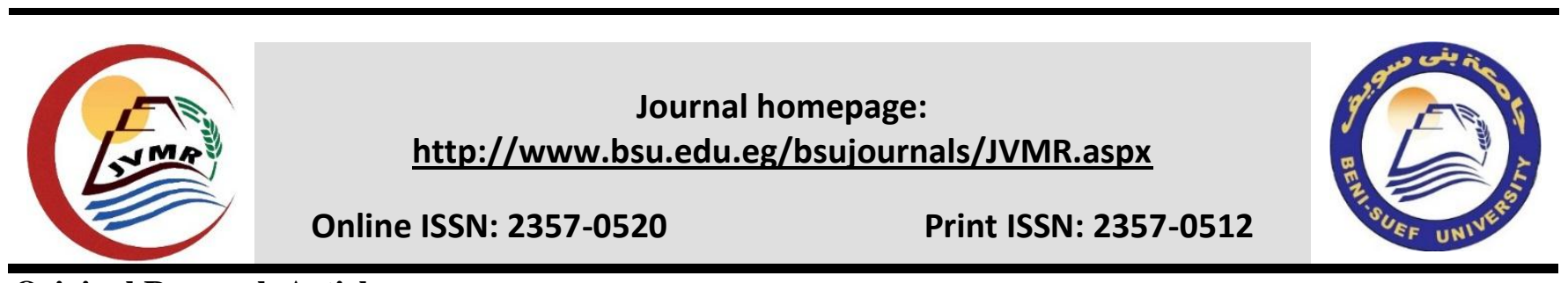

Original Research Article

\title{
Antioxidant, immunostimulant and renal protective activities of tri-herbal combination in African Sharptooth Catfish, Clarias gariepinus
}

\author{
Walaa F.A. Emeish ${ }^{1 *}$ Zeinab Al-Amgad ${ }^{2}$ and Hassan Ahmed ${ }^{3}$ \\ ${ }^{1}$ Department of Fish Diseases, Faculty of Veterinary Medicine, South Valley University, Qena 83523, Egypt. \\ ${ }^{2}$ Veterinary National Service, PhD in Veterinary Pathology and Clinical Pathology, Faculty of Veterinary \\ Medicine, South Valley University, Qena, Egypt. \\ ${ }^{3}$ Department of Physiology, Faculty of Veterinary Medicine, South Valley University, Qena 83523, Egypt.
}

\begin{abstract}
Medicinal herbal feed that used as feed additives are widely applied in livestock production and may be applicable to aquaculture production systems. The present study explores the modulatory effects of incorporation of herbal combination of black cumin seeds (Nigella sativa), peppermint (Mentha piperita) and fennel (Foeniculum vulgare), on African Sharptooth Catfish, Clarias gariepinus. For this purpose, a total of 72 catfish were randomly distributed into 6 groups of 12 fish each and fed on the experimental diets for 45 successive days. Fish of first group were fed on basic diet only while, those of the second one were fed on basic diet supplemented with $0.5 \%$ from each medicinal plant while, other 4 groups were subjected to challenge experiment by injection with Vibrio vulnificus. The third group was kept non-injected, fourth group was injected by saline, fifth and sixth groups were injected by Vibrio vulnificus after feeding with basic diet and basic diet with herbs, respectively. Results proved that, total antioxidant capacity, serum total proteins, albumins and globulins were observed to be significantly higher in the treated group as compared to the control. Lymphocytes percent increased significantly in herbal fed group comparing to the control group while, neutrophils percent decreased significantly. Although serum urea level was not affected by herbal supplement, serum creatinine level was decreased significantly. Body weight gain of $\mathrm{C}$. gariepinus increased significantly after herbal administration. Catfish challenged with a Vibrio vulnificus isolate and received the herbal diet showed less mortality than the control group. Fish fed on the herbal diet exhibited normal histological structure of liver, kidney and spleen. In conclusion, based on the current results together with the low cost and the potential antioxidant and immune effects of mixed herbal medicinal plants used in the study, it is recommended to be used in fish feed to diminish the mortalities caused by some aquatic pathogens.
\end{abstract}

*Corresponding author. Department of Fish Diseases, Faculty of Veterinary Medicine, South Valley University, Qena 83523, Egypt.Email: walaa@vet.svu.edu.eg 


\section{Introduction}

Many immunostimulants are being used as feed supplement in fish farms to prevent fish from pathogenic organisms. However, some disadvantages inhibit its use (Sakai, 1999). The extra financial burden on fish raisers of the immunostimulant is important factor (Dügenci et al., 2003). With the outright ban on feed additives, new alternative strategies of ameliorating and conserve the health status of fish and consequently fish production must be explored. The application of naturally occurring immunostimulants such as, herbs, herbal preparations and other botanicals are prioritize over chemical compounds for augmentation of fish health and enhance the activities of nonspecific defense mechanisms.

Oxidative stress is a process characterized by alteration of balance between radicals generating and radical-scavengers activities resulting in reduction of antioxidant protection (Bernabucci et al., 2002). Oxidative stress is a primary problem that adversely affects physiological condition and production performance of aquaculture, but synthetic antioxidants have a toxic and carcinogenic effects (Shahidi 2005) so, it is important to sought antioxidant with natural source to ameliorate theses deleterious effects.

The use of plants becomes necessary because of their wide medicinal importance (Zhang, 2002). Among these plants, black cumin seed, Nigella sativa which is a spice and used as a preservative in foods. It encompasses many therapeutic properties such as, antibacterial, antifungal, anti-inflammatory (Khan, 1999), immunomodulator, hepatoprotective and renal protective (Ramadan, 2007).

Mint species, Mentha piperita (also known as peppermint) belonging to Lamiaceae family (Iscan et al., 2002). Peppermint is an aromatic plant used as a kind of traditional therapy such as gastrointestinal troubles as it can be used as appetizer and exert relaxation on stomach wall (McKay and Blumberg, 2006). Moreover, peppermint has antiseptic properties (Rakover et al., 2008), antioxidant, antiviral, fungicide and antibacterial activities (McKay and Blumberg, 2006).

Fennel (Foeniculum vulgare) is an aromatic herb also used in medicinal plant and as spice in Central Europe and the Mediterranean. Fennel is known as an excellent source of natural antioxidants and participates in daily antioxidant diet (Shahat et al., 2011). From all that, the present study aimed to investigate the influence of mixed tri-herbal medicinal plants on growth rates of African Sharptooth Catfish, C. gariepinus, its antioxidant and immunostimulatory activities via changes in various immunological measures. In addition, its impacts on resistance to $\mathrm{V}$. vulnificus in challenge infection test. Moreover, the protective effect on reducing the histopathological alteration in structure of kidney, liver and spleen were also considered.

\section{Materials and methods}

Fish samples

African Catfish (C. gariepinus) $(\mathrm{n}=72)$ with average weight $50 \pm 5 \mathrm{~g}$ were collected from private fish farm in El- Dakahlea Governorate, Egypt. The fish were transported to the Aquatic Research Laboratory, Faculty of Veterinary Medicine, South Valley University, Qena, Egypt. Acclimatization period was 21 days in porcelain aquaria $(260 \times 65 \times 70 \mathrm{Cm})$ according to the protocol of maintaining bioassay fish as was previously described (Ellsaesser and Clem, 1986). The fish were fed with basal diet without herbal supplement twice daily with a feeding rate of 3\% of their body weight (El Kamel and Mosaad, 2012) until the beginning of the experiment. Water change rate was seventy percent daily with dechlorinated stagnant tap water, the fecal matters were removed out daily and dissolved oxygen level maintained by aerators.

\section{Preparation of medicinal herbs}

Nigella sativa, Foeniculum vulgare seeds and Mentha piperita leaves were bought from the local market, from Qena, Egypt. The seeds and leaves were washed by water, air dried and 
ground before mixing with the basal diet. Basal diet (control) alone or plus tri-herbal supplement were formulated from natural ingredients and herbal mixture as listed in Table 1 . The dietary ingredients were thoroughly mixed by a hand palletizer. The pellets allowed to air-dry at room temperature and stored at $-5^{\circ} \mathrm{C}$ until use. The required amount of the diet was prepared every week.

Fish and experimental design Table 1: Dietary composition used in the present study

\begin{tabular}{lll} 
& Basal diet & Herbal diet \\
\hline Nigella sativa & - & $0.5 \%$ \\
\hline Mentha piperita & - & $0.5 \%$ \\
\hline Foeniculum vulgare & - & $0.5 \%$ \\
\hline yellow corn & $34.9 \%$ & $34.9 \%$ \\
\hline vegetable bean meal & $28.6 \%$ & $28.6 \%$ \\
\hline fish meal & $17.0 \%$ & $17.0 \%$ \\
\hline wheat bran & $9.3 \%$ & $9.3 \%$ \\
\hline mineral mixture & $1.7 \%$ & $1.7 \%$ \\
\hline vitamin mixture & $1.0 \%$ & $1.0 \%$ \\
\hline
\end{tabular}

\section{Table 2: Experimental design used in the present study:}

I- Experiment 1 (for biochemical analysis)

\begin{tabular}{ll}
\hline Group 1 & Fish fed on basal diet (Control) for blood samples. \\
\hline Group 2 & Fish fed on basal diet supplemented with Nigella, peppermint and fennel of 0.5\% each of diet weight for \\
& blood samples. \\
\hline
\end{tabular}

II- Experiment 2 (challenge experiment)

\begin{tabular}{ll}
\hline Group 3 & Fish fed on basal diet (Control) for challenge experiment. \\
\hline Group 4 & $\begin{array}{l}\text { Fish fed on basal diet supplemented with Nigella, peppermint and fennel of 0.5\% each of diet weight for } \\
\text { challenge experiment. }\end{array}$ \\
\hline Group 5 & Fish fed on basal diet injected with saline (+ve control) for challenge experiment. \\
\hline Group 6 & Fish fed on basal diet (-ve control) for challenge experiment. \\
\hline
\end{tabular}


Fish were fed twice daily for 45 successive days and body weight was recorded at the beginning and the end of the experiments.

\section{Blood sampling}

After 45 days, fish of all groups were quickly anesthetized using tricaine methanesulfonate (MS-222, Argent Chemical Labs, Redmond, Washington, USA). Blood samples were collected from caudal vein of groups 1 and 2 in Eppendorf tubes. The blood was left to clot for 2 hours at $4^{\circ} \mathrm{C}$ and then centrifuged at $3000 \mathrm{rpm}$ for $15 \mathrm{~min}$, sera were collected and kept at $20^{\circ} \mathrm{C}$ for the biochemical analysis.

For differential leukocytic count blood smears were made immediately, air dried, fixed with alcohol, stained by Giemsa stain and examined under light microscope. The cells were identified according to the morphological features according to Stoskopf (1993).

\section{Biochemical methods}

All biochemical parameters were analyzed spectrophotometrically

(Visible

Spectrophotometer 723C, Shanghai Phenix Optical Scientific Instrument Co., Ltd, Shanghai, China) according to standard methods using commercial laboratory kits. Total antioxidant capacity (TAC) was carried out according to Koracevic et al. (2001) by using commercial kits (Bio-Diagnostics Ltd., Worcestershire, United Kingdom). Serum total proteins (g/dl) and albumins (g/dl) were estimated according to the methods described by Doumas et al. (1971) and Kaplan and Szabo (1983) respectively. Total proteins and albumins kits (Spectrum Diagnostics, Obour City, Egypt) were used. Serum globulin (g/dl) was calculated according to Busher (1990) by mathematically subtracting albumins value from total proteins value. The methods of young et al. (1975) and Tietz (1986) respectively, were used to determined serum urea and serum creatinine (Egy-chem, Badr city, Egypt).

\section{Challenge experiment \\ Bacterial strain}

Vibrio vulnificus strain was isolated from clinical cases of naturally infected catfish showing signs of septicemia. The strain was identified according to Austin and Austin (2007) and preserved in glycerol at $-80^{\circ} \mathrm{C}$. To restore its pathogenicity, it was passed three times via intra-peritoneal injection in C. gariepinus before using for experimental infection.

\section{Experimental dose}

The bacterial count (colony forming units "CFU") was measured by both Spectrophotometric and standard-plate-count method. For spectrophotometry, optical density values were measured to know the counts in bacterial suspensions at wavelength of $600 \mathrm{~nm}$. For standard plate count method, bacterial suspensions were ten-fold serially diluted (Goldman and Green, 2015). The experimental dose was determined depending on preliminary work.

\section{Experimental infection}

At the end of each experimental periods (45 days); fish of groups 3 and 4 were ip injected with $0.5 \mathrm{ml}$ of sterile saline containing $1.3 \times 105$ $\mathrm{cfu} / \mathrm{ml}$ pathogenic strain of $V$. vulnificus, a +ve control group $(\mathrm{n}=12)$ (group 5) were ip injected with sterile saline while, -ve control group $(n=12)$ (group 6) was remained non-injected. The challenge trial lasted for 21 days. Mortality rate was recorded, and dead fish were removed daily and subjected to bacterial re-isolation and identification.

\section{Gross and histopathological study}

After body weighing and blood collection, liver, kidney and spleen were inspected for detection of any gross lesions then dissected out and kept in formalin $10 \%$ for $24 \mathrm{~h}$. Organs were washed and dehydrated in ascending concentrations of ethanol, cleared in xylene and embedded in paraffin wax. Sections of about 4-5 $\mu \mathrm{m}$ thickness were prepared and then stained 
with haematoxylin and eosin for histopathological examination (Bancroft and Gamble, 2008).

\section{Statistical analysis}

Results were statistically analyzed using the Graph-Pad Prism (GraphPad Software, San Diego, CA, USA). Values were expressed as mean \pm standard error of mean (SEM) and differences between groups were analyzed by using Student's t-test, results were considered significant at the $\mathrm{P}<0.05$ level.

\section{Results}

During the 45 days of feeding trials, there was no mortality or abnormal fish behavior in all groups.

Results of the current study are presented in Table 3. It appears from Table 3 and Fig. 1A

\section{Table 3: Biochemical analysis in herbal and basic diet fed fish:}

\section{Control}

that serum level of TAC significantly increased $(\mathrm{P}<0.05)$ in catfish fed on tri-herbal mixture compared with those fed on basic diet. total proteins, globulins and lymphocytes percent showed significant increase after feeding on herbal mixture (Figs. 1B and $\mathrm{C}$ respectively). Besides, significant increase $(\mathrm{P}<0.05)$ of albumins after herbal combination was also detected (Fig 1B). Although globulins were significantly increased in herbal treated fish, there is no change in $\mathrm{A} / \mathrm{G}$ ration between treated and control groups (Table 3). Serum creatinine level decreased significantly $(\mathrm{P}<0.001)$ in herbal treated catfish compared with those fed on basic diet while, serum urea level almost showed no change between treated and control groups (Fig. 2).

\begin{tabular}{|c|c|c|}
\hline & Control & Herbs treated \\
\hline $\begin{array}{l}\text { Total antioxidant } \\
\text { capacity }(\mathrm{mmol} / \mathrm{L})\end{array}$ & $0.32 \pm 0.01$ & $0.41 \pm 0.03 *$ \\
\hline Globulins (g/dl) & $6.05 \pm 0.16$ & $6.53 \pm 0.16^{*}$ \\
\hline A/G ratio (\%) & $0.34 \pm 0.01$ & $0.34 \pm 0.02$ \\
\hline Total proteins $(\mathrm{g} / \mathrm{d})$ & $8.11 \pm 0.14$ & $8.86 \pm 0.20 * *$ \\
\hline Albumins (g/dl) & $2.06 \pm 0.04$ & $2.33 \pm 0.07 * *$ \\
\hline Lymphocytes (\%) & $70.08 \pm 1.76$ & $87.42 \pm 0.38 * * *$ \\
\hline Neutrophils (\%) & $26.67 \pm 1.73$ & $9.50 \pm 1.15 * * *$ \\
\hline Monocytes (\%) & $2.42 \pm 0.70$ & $1.92 \pm 0.38$ \\
\hline Esinophils (\%) & $0.25 \pm 0.13$ & $0.33 \pm 0.14$ \\
\hline Basophils (\%) & $0.58 \pm 0.19$ & $0.75 \pm 0.22$ \\
\hline Creatinine (mg/dl) & $0.45 \pm 0.02$ & $0.34 \pm 0.01 * * *$ \\
\hline Urea (mg/dl) & $8.23 \pm 0.29$ & $8.35 \pm 0.25$ \\
\hline Body weight gain (g) & $41.12 \pm 1.42$ & $54.96 \pm 6.23 *$ \\
\hline Mortality rate (\%) & $41.7 \pm 1.25$ & $75.00 \pm 1.46^{*}$ \\
\hline
\end{tabular}


Fig. 3A showed significant increase $(\mathrm{P}<0.05)$ in body weight gain after administration of triherbal mixture compared with control. The percent of survival and mortality of $C$. gariepinus infected with pathogenic strain of $V$. vulnificus showed that, mortality rate significantly lower $(\mathrm{P}<0.05)$ in herbal fish (group 4) than the basic diet fed fish (group 3) (Fig. 3B) while, there is no mortality rates in +ve and -ve groups. Post mortem findings of dead fish showed signs of septicemia, however the clinical signs reported were less severe in the herbal treated group.

Macroscopically, the scarified catfish of the control group demonstrated normal brown discoloration of the liver suffered from some paleness in some areas. Kidney was apparently healthy. Spleen appeared slightly congested and moderately enlarged. Herbal-treated fish showed liver, kidney and spleen with normal appearance either sizes or shapes.

Microscopically, the liver of the control catfish exhibited mild degree of vacuolar and hydropic degeneration of the hepatocytes with moderate congestion in the blood vessels mainly central vein (Figs. 4 a \& b). Treated liver showed normal arranged hepatocytes within normal shapes and sizes; as well as focal aggregation of the melanomacrophages was detected adjacent to blood vessels (Fig. 4 c). In addition, the hepatic blood vessels appeared apparently intact; therein central vein seemed within normal shapes and sizes (Fig. 4 d).
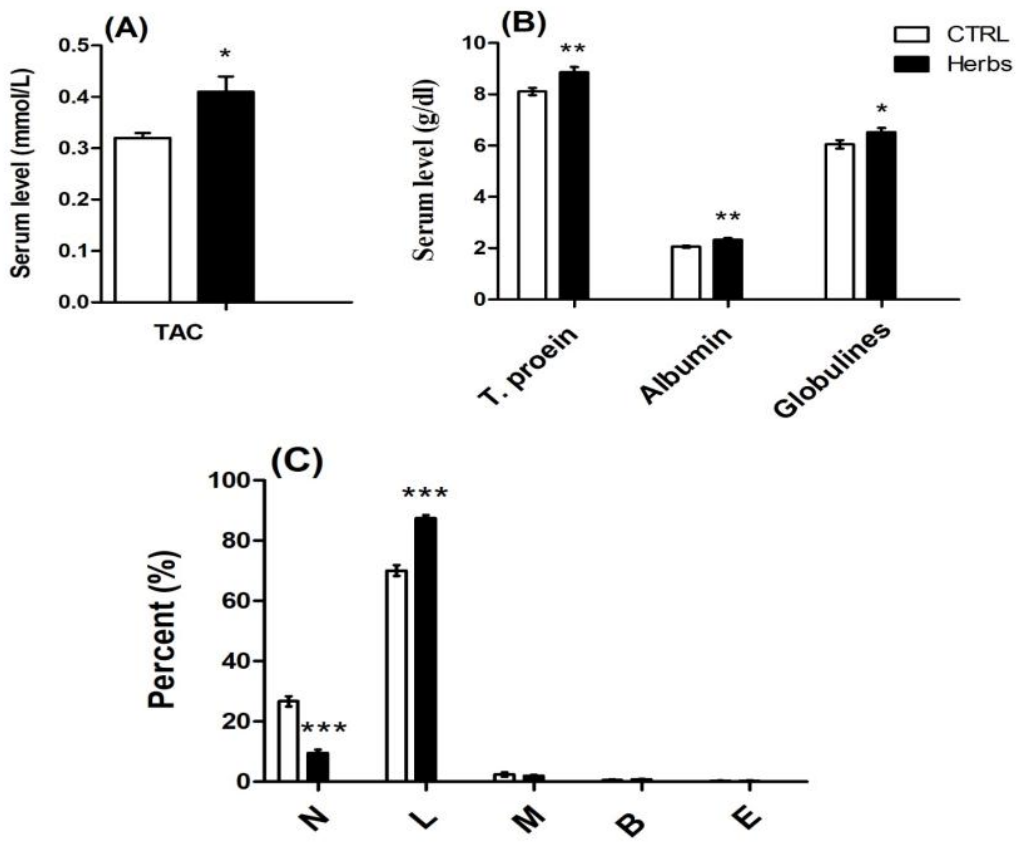

Fig. 1: Serum level of total antioxidant capacity (A), total proteins, albumins and globulins (B) as well as differential leukocytic count (C) in response to administration of Nigella Sativa, Mentha Piperita and Foeniculum Vulgare for 45 successive days $(\mathrm{n}=12, * \mathrm{P}<0.05, * * \mathrm{P}<0.01)$. 


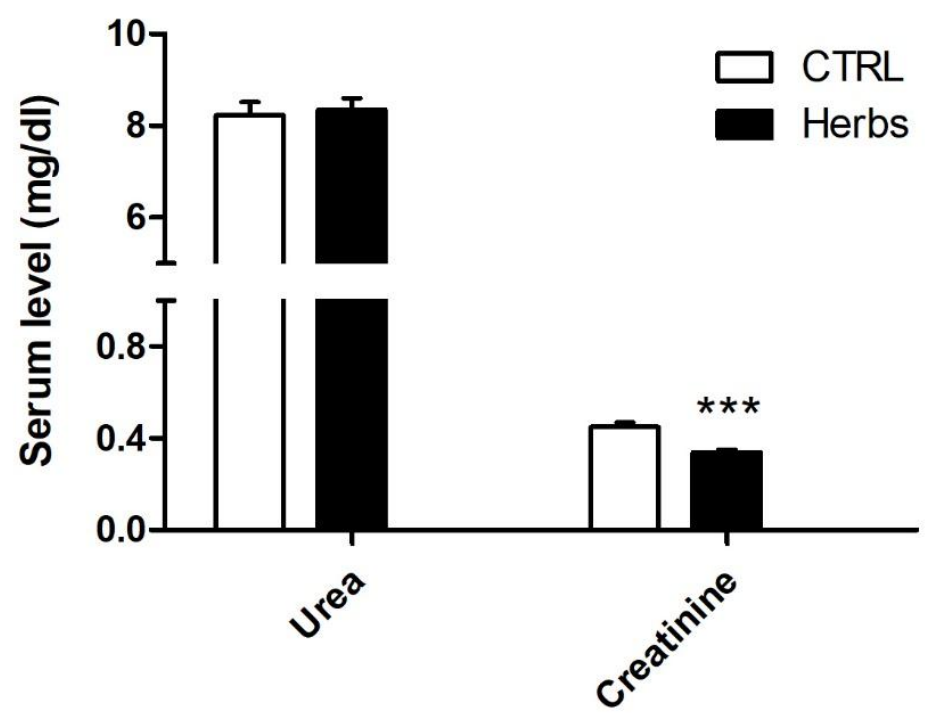

Fig. 2: Serum level of urea and creatinine represents kidney function after 45 days administration of tri-herbal combination $(\mathrm{n}=12, * * * \mathrm{P}<0.001)$.
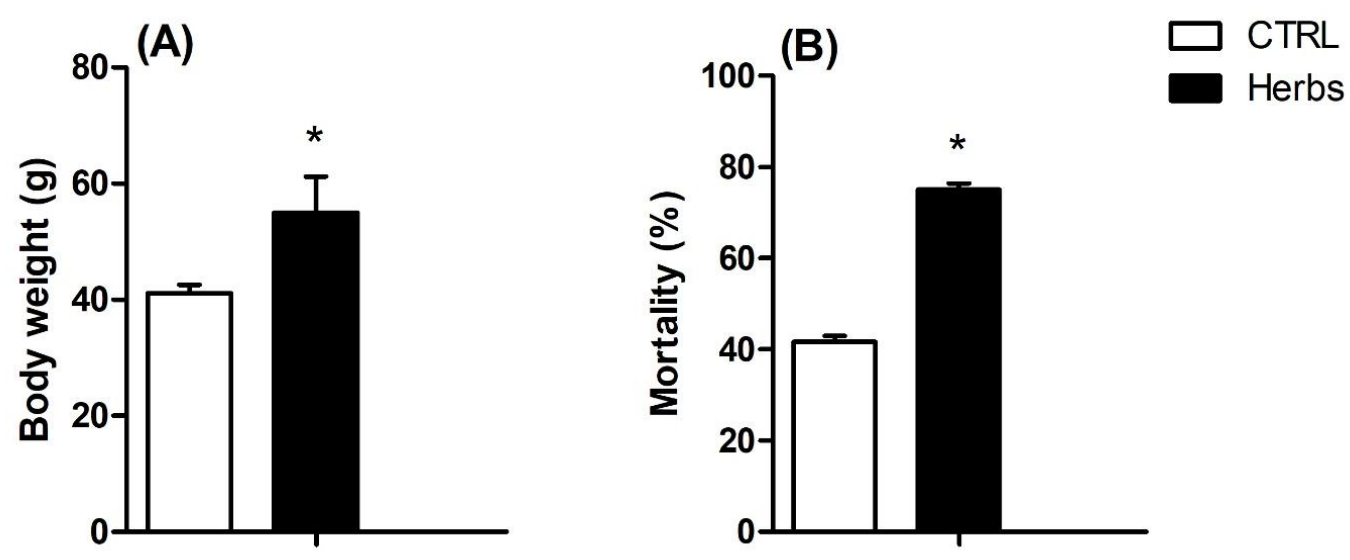

Fig. 3: Body weight gain in control and treated fish after administration of tri-herbal combination for 45 days (A). Mortality rate in control and treated fish after infection with $V$. vulnificus $(\mathrm{n}=12, * \mathrm{P}<0.05)$. 

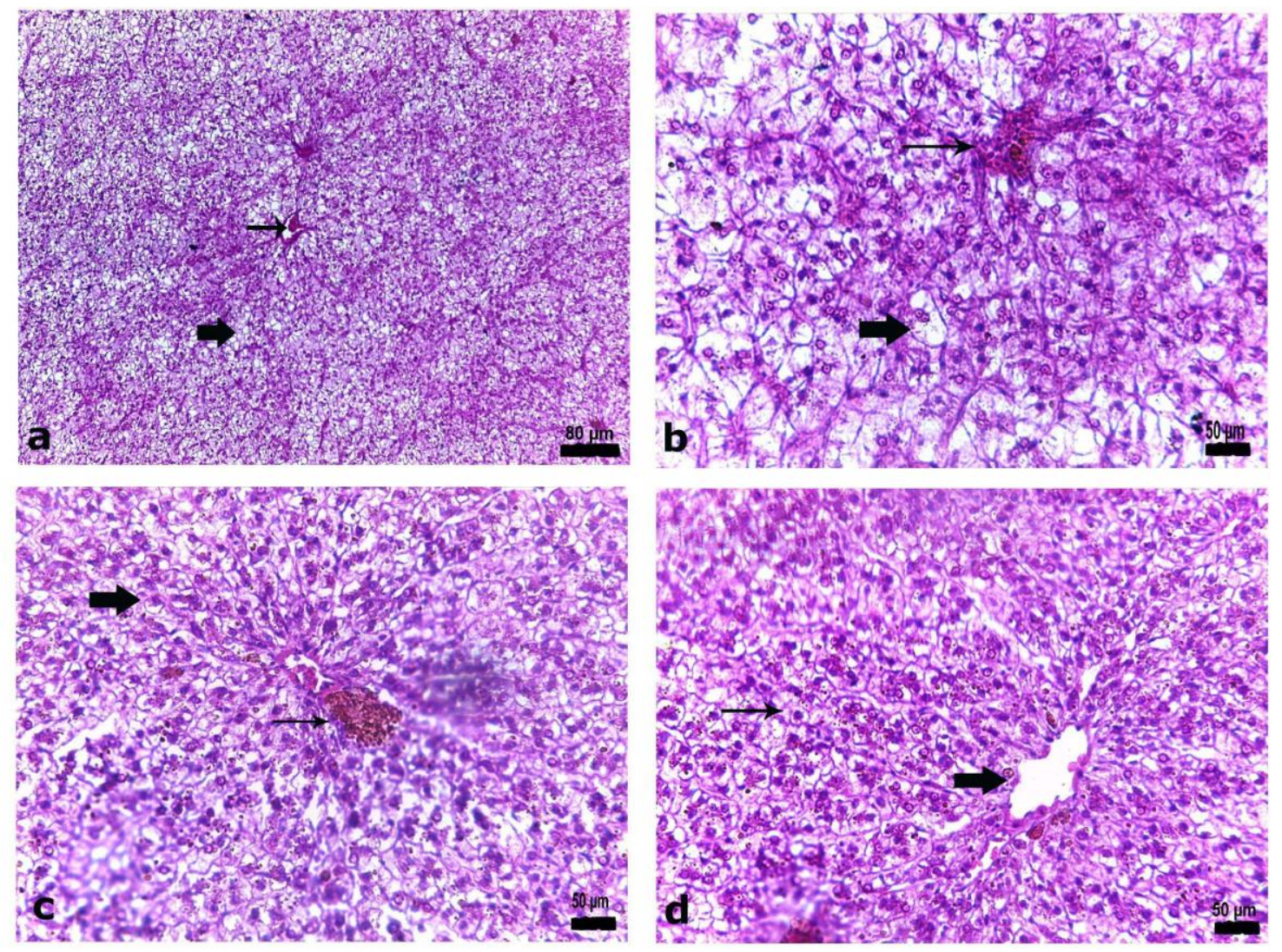

Fig. 4 (a-b): Photomicrograph of the liver of the control catfish showing cytoplasmic vacuolation of the hepatocytes (thick arrow) with mild congestion in the central vein (thin arrow) (a). High power of plate a to show cytoplasmic vacuolation of the hepatocytes (thick arrow) with mild congestion in the central vein (thin arrow) (b). Fig. (c-d): Photomicrograph of the liver of the treated catfish showing normal arranged hepatocytes (thick arrow) and focal infiltration of the melanomacrophage (thin arrow) (c), normal architecture of the liver with normal hepatocytes (thin arrow) and normal blood vessels (thick arrow) (d). (H\&E., bar $=50 \& 80 \mu \mathrm{m})$.

The posterior renal tissues of the control group displayed necrosis with sloughing of the epithelial lining renal tubules toward the lumen (Fig. 5 a). While, the glomeruli appeared apparently healthy in addition, there was focal aggregation the melanomacrophages and hemosiderin (Fig. 5 b). On the contrary, the treated group showed normal nephrons with intact renal corpuscles, besides normal haemopoietic tissues (Fig. 5 c). Moreover, mild distribution the melanomacrophages and hemosiderin was detected (Fig. 5 d).
Spleen of the control catfish revealed mild degree of lymphoid depletion of the white pulp with focal infiltration the melanomacrophage (Figs. 6 a \& b). Mild congestion in the blood vessels was observed in the control spleen (Fig. $6 \mathrm{c})$. On the contrast, the red pulp displayed normal histological architecture (Fig. 6 d). The treated catfish exhibited normal splenic architecture of normal white and red pulps (Fig. 6 e); besides mild aggregation the melanomacrophages was noticed (Fig. 6 f). 

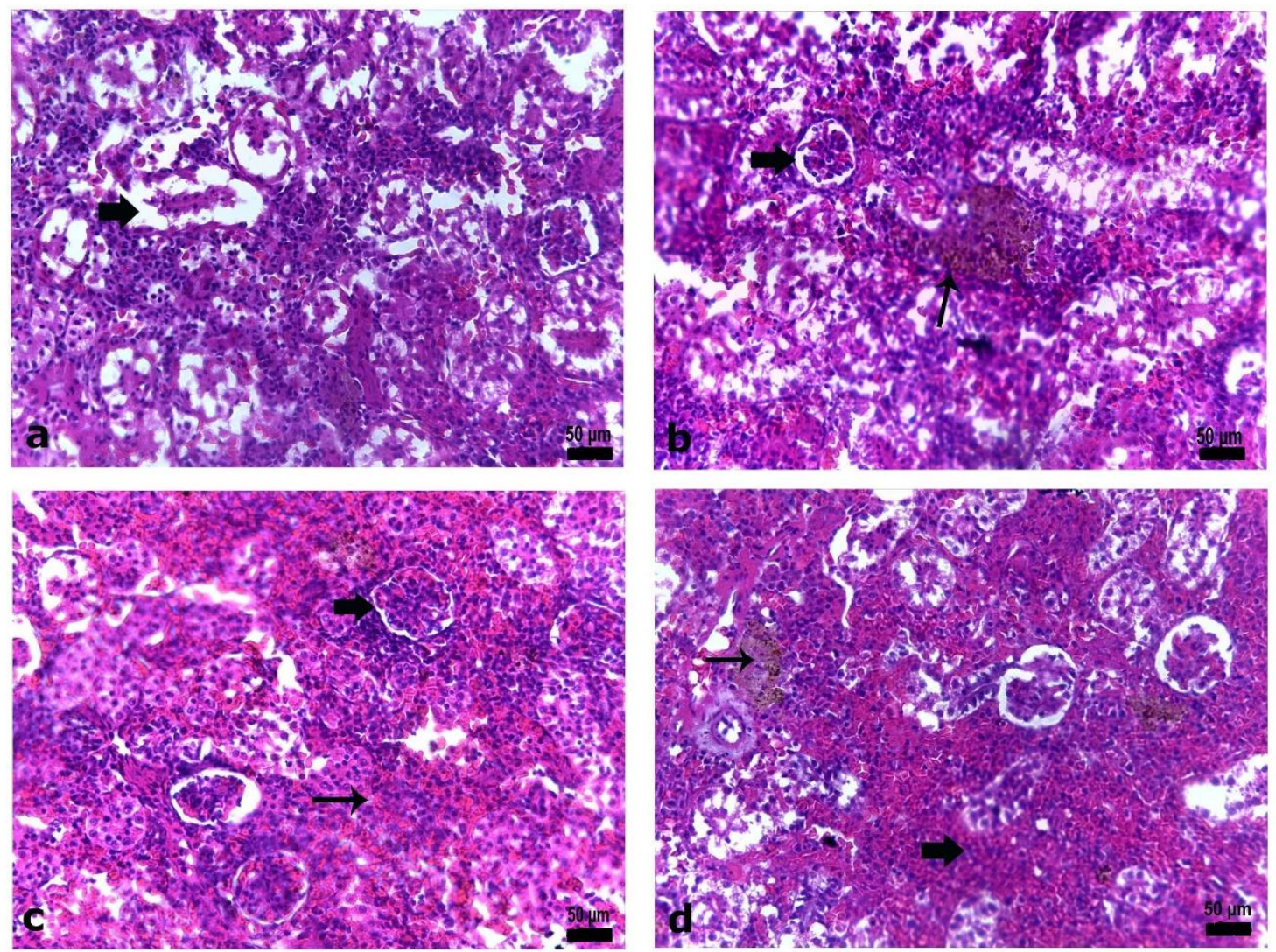

Fig. 5 (a-b): Photomicrograph of the posterior kidney of the control catfish showing renal tubular necrosis with sloughing of the epithelial lining (a), normal glomeruli (thick arrow) with focal aggregation the melanomacrophages and hemosiderin (thin arrow) (b). Fig. 5 (c-d): Photomicrograph of the posterior kidney of the treated catfish showing normal renal corpuscles (thick arrow) and normal haemopoietic tissues (thin arrow). (c), mild aggregation the melanomacrophages and hemosiderin (thin arrow) and normal haemopoietic tissues (thick arrow) (d). (H\&E., bar $=50 \& 80 \mu \mathrm{m})$. 


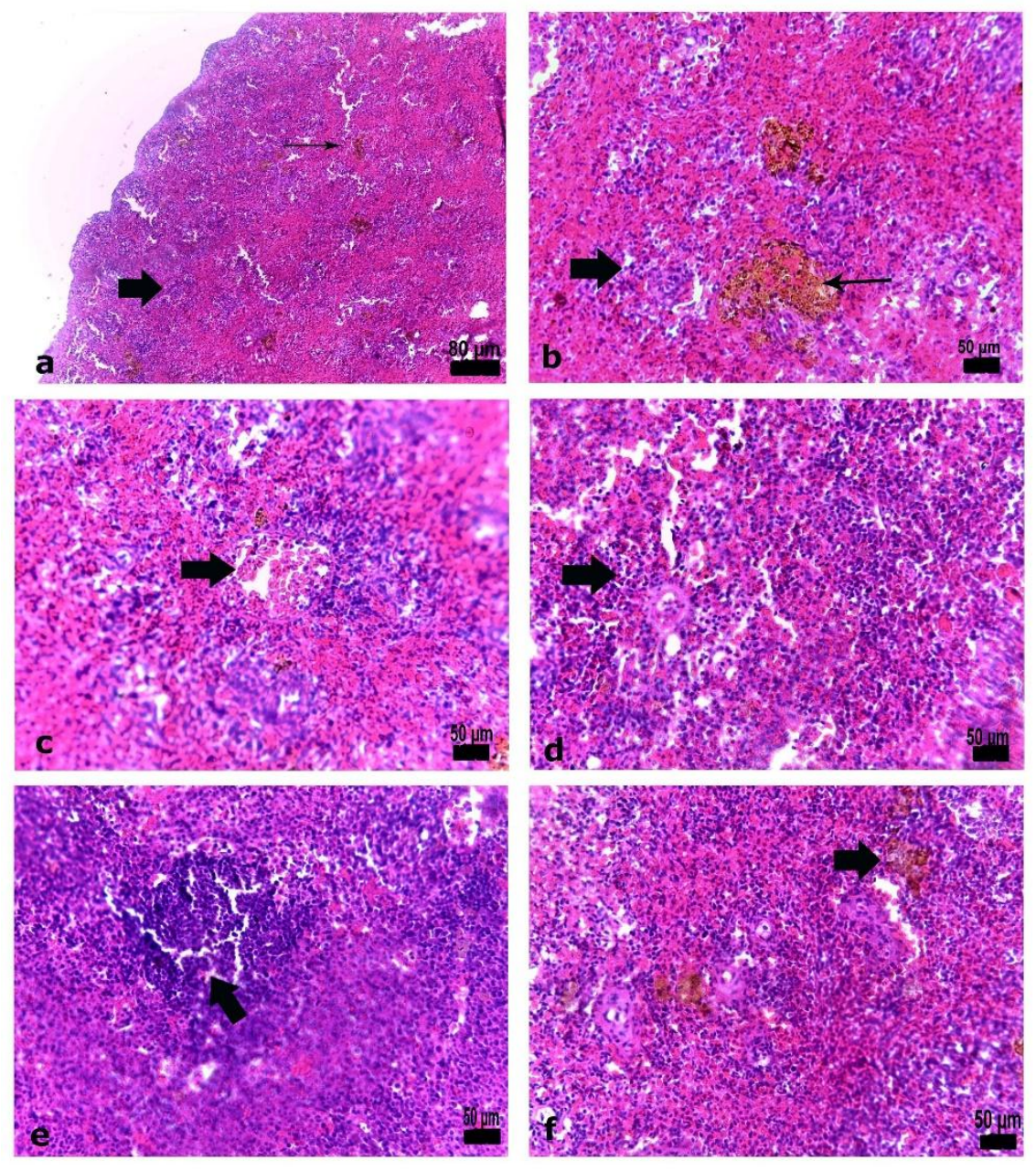

Fig. 6 (a-d): Photomicrograph of the spleen of the control catfish showing mild lymphoid depletion of the white pulp (thick arrow) with focal aggregation the melanomacrophages (thin arrow) (a). High power of plate a to show mild lymphoid depletion of the white pulp (thick arrow) with focal aggregation the melanomacrophages (thin arrow) (b), mild congestion in the blood vessels (c), normal histological architecture of the red pulp (d). Fig. 6 (ef): Photomicrograph of the spleen of the treated catfish showing normal splenic architecture (e), mild infiltration of the melanomacrophages (f). (H\&E., bar $=50 \& 80 \mu \mathrm{m})$.

\section{Discussion}

Antimicrobials and vaccination for disease control strategy have suppressed the fish growth with subsequent generation of bacterial resistance and accumulation of antimicrobial agents in fish products. Therefore, their use in aquatic life become criticized (Gulec et al., 2013). For these important considerations, one of the most auspicious methods of curing or preventing diseases in fish farms is by modulating the defense mechanism of fish through prophylactic application of products originated from natural plants (Agarwal and Singh, 1999 and Devasagayam and Sainis, 2002) The present study aimed to investigate the potential effects of black cumin seed, peppermint and fennel combinations on the antioxidant capacity, immune response and renal protective activities in $C$. gariepinus, with consequent study of the disease resistance ability. Moreover, histopathological 
investigation of liver, kidney and spleen were also considered.

Plants contain antioxidant activity that gives protection against risky oxidative deterioration (Charles, 2013). Black cumin seed, peppermint and fennel are considered excellent source of natural antioxidant, and this could be proved in the current study. Increased level of antioxidants in laboratory rats with acute toxic hepatitis was recorded by Katikova et al. (2001) after feeding on the extract of peppermint leaf. Level of serum glutathione peroxidase and catalase activities as enzymatic antioxidant showed significant increase in C. gariepinus fed on diets contained either fenugreek or thyme compared to the control group (Emeish and Saad El- Deen, 2016).

Different types of white blood cells (WBCs) contribute in the cellular immunity, including lymphocytes and other granulocytes (Nakanishi, 1999) and play important role in the cellular immune response and resistance to infectious pathogens (Whyte, 2007). Their functions can be boosted by natural immunostimulants as was previously reported in gold fish that were supplemented with mixtures of chosen herbs (Harikrishnan et al., 2010). Although, percent of lymphocytes significantly increased in the present study, the percent of other WBCs types (neutrophils, monocytes, basophils and eosinophils) decreased in herbal treated group compared with control one owing to the high percent of lymphocytes. Monocytes and eosinophils showed no significant differences in fry Caspian white fish (Rutilus frisii kutum) fed on peppermint extracts (Adel et al., 2015), while the percent of neutrophils and lymphocytes increased and decreased, respectively.

Serum proteins and immunoglobulin levels are a major indicator of humoral part of innate immune system of fish (Secombes and Fletcher, 1992; Magnadóttir, 2006) which is the primitive line of defense against infectious pathogens. Serum total proteins and total globulins levels in herbal group showed significantly higher levels than the control one, indicating the immune stimulating effects of tri-herbs used. Similar results were reported that total proteins in serum was elevated in fish after administration of $1 \%$ ginger (Dugenci et al., 2003) and in rainbow trout fed on Nigella sativa (Dorucu et al., 2009). IgM level was increased in fry Caspian white fish (Rutilus frisii kutum) fed on peppermint extracts (Adel et al., 2015).

Urea level which is an indicator of kidney function is not affected by mixed herbal immunostimulant used. On the other hand, creatinine level was significantly decreased in herbal diet group. Feeding rats on Nigella sativa seeds leads to significant decrease in serum urea and creatinine level during exposure to lead acetate toxicity (Farrag et al., 2007) and anticancer drugs (Ali and Blunden, 2003). Nigella sativa increases serum total proteins, decrease level of amino acids circulating in the blood subsequently, declines deamination lead to less formation of non-proteins nitrogenous compound including creatinine (Al-Logmani and Zari, 2011). Moreover, peppermint also, has the nephroprotective effect due to its phytocompounds as menthol (35.9\%) and menthone (25.6\%) (Chaves et al., 2011). Ullah et al. (2014) and Khalil et al. (2015) agree with the present results as serum creatinine level decreased after administration of peppermint alone or mixed with other medicinal plants in experimental animals. Likewise, Nigella Sativa, Fennel has the ability to elevate serum level of total proteins and albumins subsequently, attenuates level of non-protein nitrogenous compounds including urea and creatinine (AlMasri and Ali, 2013). From the previous findings it is clear that Nigella Sativa, peppermint and fennel had individual nephroprotective effect so, in the current study the tri-herbal combination augments and improves the renal function.

The body weight gain among treatment group fed herbal supplemented diet implies that they had effect on growth. Weight gain was increased in fry Caspian white fish (Rutilus frisii kutum) fed on peppermint extracts (Adel et al., 
2015). Also, Nigella Sativa increased serum level of total proteins and albumins an it is expected its anabolic role in tissue growth and development and reflecting as increase body weight gain. In addition, the present results match with the previous findings which proved increase body weight gain after administration of fennel (Al-Masri and Ali, 2013) and peppermint (Khalil et al., 2015).

From the result of challenge experiment, it was revealed antibacterial and immune modulatory activities of herbal combination used. They have positively impacted the resistance of fish to $\mathrm{V}$. vulnificus infection as was indicated by the decreased mortality and severity of clinical signs in fish fed on the herbal combination. Fennel extracts exerted the protection activity against acute and subacute inflammatory disorders and showed a central tranquilizer effect (Choi and Hwang, 2004). Peppermint has antiseptic, antimicrobial and anti-inflammatory characteristics. The major component of peppermint essential oil was menthol which is characterized by antimicrobial effect (Iscan et al., 2002). It possesses excellent antimicrobial activities against E. coli, Staphylococcus aureus, and Candida albicans (Yadegarinia et al. 2006). Also, alcoholic extract of the Nigella seed was shown to have antibacterial activity against $\mathrm{E}$. coli and Micrococcus pyogenes var. aureus (Pruthi, 2001). Elkamel and Mossad (2012) stated that, the mortality rate of Nile tilapia fed with black cumin ration and challenged with $A$. hydrophila was significantly lower than those that received the basic diet. Also, the mortality rate of $\mathrm{C}$. gariepinus fed with either fenugreek or thyme rations and challenged with $\mathrm{A}$. hydrophila was significantly lower than those that received the basic diet (Emeish and Saad El-Deen, 2016).

The treated catfish with herbal plants restored normal histological appearance and architecture either grossly or microscopically as observed in liver, kidney and spleen. It is attributed to wide potential specific protective effect of the herbal plants on tissues. Nigella sativa grant protection against hepato-nephrotoxicity induced either by disease or chemicals; as well as it could provide cardioprotective, neuroprotective, lung protective and gastroprotective activities (Darakhshan et al. 2015). Nigella sativa is high in biological active compounds; in addition to it offered an antioxidant activity in different organs lead to neutralize the oxygen free radicals generated (Burits and Bucar, 2000). Moreover, it has variety of therapeutic effects as anti-inflammatory, anti-cancer, antihistaminic and antibacterial. Also, it has been mentioned that Nigella sativa possess immunomodulatory and anti-neoplastic effects in many previous experimental studies (Morsi, 2000).

The restoration of the normal tissues structure induced by Peppermint suggested its protective activity which may be attributed to the free radical-scavenging properties of flavonoids (Kalpana and Alkal, 2012). Mint has antioxidant property prevent oxidative stress in tissues (Ortmann et al., 2004) since; it has scavenging compounds like monoterpene ketones, menthone, and isomenthone. Peppermint enhances regeneration and increase rate of restoration of liver cells through increase number of hepatic nucleus and intracellular RNA concentration (Vokovic-Gacic and Simic, 1993). It intended to fasten recovery of the dead and damaged tissues through rapid removal of the cellular debris (Samarth and Kumar, 2003). So, it offered protection against oxygen derivedfree radicals and cellular damage (Baliga et al., 2003). Also, it considered as an effective antiallergic, antispasmodic plant (Samarth et al., 2006) and anticarcinogenic mechanism (Jain et al., 2011).

Fennel is medicinal herbal plant can give a protective power against many chemically induced damages in liver and kidney cells because it contains adequate amount of many antioxidants (Hanefi et al., 2004). The phytochemical composition of fennel revealed presence of many active components such as thymol, carvacrol, terpinenes, P-thymene and thymol methyl ether, phenolic glycosides, 
flavonoids, phytosterols-triterp and saponins which have antioxidant and free radical scavenging activity. It led to reduce the amount of reactive oxygen species generated by fatty acid peroxidation; it also minimized the DNA damage produced (Naglaa et al., 2010).

\section{Conclusions}

It could be concluded from the current study that combination of black cumin seeds (Nigella sativa), peppermint (Mentha piperita) and fennel (Foeniculum vulgare) in the fish diet can influence the total antioxidant capacity, immune response and renal activity which subsequently stimulated the resistance of fish to $\mathrm{V}$. vulnificus infection. Moreover, addition of these herbal mixture as herbal feed additives could reestablish the normal histological structure of tissues.

\section{References}

Adel M, Amiri AA, Zorriehzahra J, Nematolahi A, Esteban A (2015). Effects of dietary peppermint (Mentha piperita) on growth performance, chemical body composition and hematological and immune parameters of fry Caspian white fish (Rutilus frisii kutum). Fish \& Shellfish Immunology, 45 (2), 841847.

Agarwal SS, Singh VK (1999). Immunomodulators studies on Indian medicinal plants and synthetic peptides. Part 1: medicinal plants. Proc Indian Natl Sci Acad 65: 179-204.

Ali BH, Blunden G (2003). Pharmacological and toxicological properties of Nigella sativa. Phytotherapy Research, 17: 299-305.

Al-Logmani A, Zari T (2011). Long-term effects of Nigella sativa L. oil on some physiological parameters in normal and streptozotocin-induced diabetic rats. Journal of Diabetes Mellitus, 1: 46-53.

Al-Masri SA, Ali W Sh (2013). The Ameliorating Effects of Fennel Powder, Extract and Oil on Gentamicin Induced Nephrotoxicity in Rats. J Am Sci;9(10):2025.
Austin B, Austin DA (2007). Bacterial fish pathogens disease of farmed and wild fish. Published in association with PRAXIS Pub Ltd, Springer.

Baliga MS, Jagetia GC, Rao SK, Babu K. (2003). Evaluation of nitric oxide scavenging activity of certain spices in vitro: A preliminary study. Nahrung, 47: 261-264.

Bancroft JD, Gamble M (2008) Theory and practice of histological techniques, Elsevier Health Sciences.

Bernabucci U, Ronchi B, Lacetera N, Nardone A (2002). Markers of oxidative status in plasma and erythrocytes of transition dairy cows during hot season. Journal of Dairy Science 85:2173-2179.

Burits M, Bucar F (2000). Antioxidant activity of Nigella sativa essential oil. Phytother Res., 14(5): 323-328.

Busher J (1990). Serum albumins and globulin. In: Walker HK, Hall WD, Hurst JW, editors. Clinical Methods: The History, Physical, and Laboratory Examinations. 3rd edition. Boston: Butterworths. Chapter 101.

Charles DJ (2013). Antioxidant Properties of Spices, Herbs and other Sources Springer New York Heidelberg Dordrecht London.

Choi EM, Hwang JK (2004). Antiinflammatory, analgesic and antioxidant activities of the fruit of Foeniculum vulgare. Fitoterapia 75(6):557-565.

Darakhshan S, Tahvilian R, Colagar AH (2015). Nigella sativa: A plant with multiple therapeutic implications. International Journal of Pharmacognosy, 2(5): 190-214.

Devasagayam TPA, Sainis KB (2002). Immune system and antioxidants, especially those derived from Indian medicinal plants. Indian J Exp Biol 40: 639-655.

Dorucu M, Ozesen Colak S, Ispir U, Altinterim B. Celayir Y (2009). The Effect of Black Cumin Seeds, Nigella sativa, on the Immune Response of Rainbow Trout, Oncorhynchus mykiss. Mediterranean Aquaculture Journal 2(1): 27-33. 
Doumas BT, Watson WA, Biggs HG (1971). Albumin standard and the measurement of serum albumin with bromocresol green Clin Chim Acta, 31:87-96.

Dügenci KS, Arda N, Candan A (2003). Some medicinal plants as immunostimulant for fish. Journal of Ethnopharmacology, 88, 99106.

Dugenci SK, Arda N, Candan A (2003). Some medicinal plants as immunostimulant for fish. Journal of Ethnopharmacology. 88 (1): 99-106.

Elkamel AA, Mosaad GM (2012). Immunomodulation of Nile Tilapia, Oreochromis niloticus, by Nigella sativa and Bacillus subtilis. Aquaculture Research \& Development 3 (6): 147.

Ellsaesser CF, Clem LW (1986). Hematological and immunological changes in channel catfish stressed by handing and transport. J. fish biol., 28, 511-521.

Emeish WA, Saad El-Deen AG (2016). Immunomodulatory effects of thyme and fenugreek in sharptooth catfish, Clarias gariepinus. Assiut Veterinary Medical Journal 62 (150): 1-7.

Farrag AH, Mahdy KA, Abdel Rahman GH, Osfor MM (2007). Protective effects of Nigella sativa seeds against lead-induced hepatorenal damage in male rats. Pakistan journal on biological science 10(17): 28092816.

Goldman E, Green LH (2015). Chapter 2: Quantitation of microorganisms. In: Practical handbook of microbiology, CRC Press.

Gulec AK, Danabas D, Ural M, Seker E, Arslan A, Serdar O (2013) Effect of mixed use of thyme and fennel oils on biochemical properties and electrolytes in rainbow trout as a response to Yersinia ruckeri infection. ACTA VET. BRNO, 82, 297-302.

Hanefi Ö, Serdar U, Irfan B, Ismail U, Ender E, Abdurrahman Ö, Zübeyir H (2004). Hepatoprotective effect of Foeniculum vulgare essential oil: A carbon-tetrachloride induced liver fibrosis model in rats. Scand. J. Lab. Anim. Sci. 31(1):9-17.

Harikrishnan R, Balasundaram C, Heo MS (2010). Herbal supplementation diets on hematology and innate immunity in goldfish against Aeromonas hydrophila. Fish Shellfish Immunol, 28, 354-361.

Iscan G, Kirimer N, Kurkcuoglu M, Baser KH, Demirci F (2002). Antimicrobial screening of Mentha piperita essential oils. J Agric Food Chem 50(14):3943-3946.

Iscan G, Demirci F, Kirimer N, Kurkcuoglu M, Baser KHC (2002). Antimicrobial screening of Mentha piperita essential oils. J. Agric. Food Chem., 50, 3943-3946.

Jain D, Pathak N, Khan S, Raghuram GV, Bhargava A, Samarth R, Mishra PK (2011). Evaluation of cytotoxicity and anticarcinogenic potential of Mentha leaf extracts. Int J. Toxicol., 30 (2): 225-236.

Kalpana P, Alkal M (2012). Hepatoprotective activity of Mentha arvensis Linn. Leaves against CCL4 induced liver damage in rats. Asian Pacific Journal of Tropical Disease, S223-S226.

Kaplan A, Szalbo J (1983). Clinical chemistry: Interpretation and techniques, $2^{\text {nd }}$ ed. $\mathrm{A}$ Kaplan, J Szabo, editors, p 157.

Katikova OIu, IaV K, Iagudina RI, Tishkin VS (2001). Effect of plant preparations on lipid peroxidation parameters in acute toxic hepatitis. Vopr Med Khim 47(6):593-598.

Khalil AF, Haiam O, Elkatry HO, El Mehairy HF (2015). Protective effect of peppermint and parsley leaves oils against hepatotoxicity on experimental rats. Annals of Agricultural Sciences 60 (2): 353-359.

Khan MA (1999) Chemical composition and medicinal properties of Nigella sativa Linn. Inflammopharmacology, 7 (1): 15-35.

Koracevic D, Koracevic G, Djordjevic V, Andrejevic S, Cosic V (2001). Method for the measurement of antioxidant activity in human fluids. J Clin Pathol. 54(5):356-361. 
Magnadóttir B (2006). Innate immunity of fish (overview). Fish Shellfish Immunol 20: 137151.

McKay DL, Blumberg JB (2006). A review of the bioactivity and potential health benefits of peppermint tea (Mentha piperita L.). Phytother. Res., 20, 619-633.

Morsi NM (2000). Antimicrobial effect of crude extracts of Nigella sativa on multiple antibiotics-resistant bacteria. Acta Microbiol Pol., 49: 63-74.

Naglaa ME, Halima SA, Hoda FB, Sherifa HS, Ekram SA, Fahmy KH (2010). Antimutagenic and Chemoprevention Potentialities of Sweet Fennel (Foeniculumvulgare, Mill.) hot water crude extract. Journal of American Science; 6(9):831-842.

Nakanishi T, Aoyagi K, Xia C, Dijkstra JM, Ototake M (1999). Specific cell-mediated immunity in fish. Vet Immunol Immunopathol 72: 101-109.

Ortmann EK, Mayerhofer T, Getoff N, Kodym $R$ (2004). Effect of Antioxidant vitamins on radiation induced apoptosis in cells of a human lymphoblasic cell line. Radiat. Res. 161: 48-55.

Pruthi JS (2001). Minor spices and condiments. ICAR, New Delhi, pp 1-782.

Rakover Y, Ben-Arye E, Goldstein LH (2008). The treatment of respiratory ailments with essential oils of some aromatic medicinal plants. Harefuah, 147: 783-788.

Ramadan MF (2007) Nutritional value, functional properties and nutraceutical applications of black cumin (Nigella sativa L.): an overview. International Journal of Food Science and Technology, 42: 12081218.

Sakai M (1999) Current research status of fish immunostimulants. Aquaculture, 172: 63-92.

Samarth RM, Kumar A (2003). Radioprotection of Swiss albino mice by plant extract Mentha piperita (Linn.). J Radiat Res (Tokyo), 44(2):101-119.
Samarth RM, Panwar M, Kumar M, Kumar A (2006). Protective effects of Mentha piperita Linn on benzoapyrene-induced lung carcinogenicity and mutagenicity in Swiss albino mice. Mutagenesis, 21(1): 61- 66.

Secombes CJ, Fletcher TC (1992). The role of phagocytes in the protective mechanisms of fish. Annual Review of Fish Diseases 2: 5371.

Shahat AA, Ibrahim AY, Hendawy SF, Omer EA, Hammouda FM, Abdel- Rahman FH, Saleh MA (2011). Chemical composition, antimicrobial and antioxidant activities of essential oils from organically cultivated fennel cultivars. Molecules, 16: 1366-1377.

Shahidi F (2005). Bailey's industrial oil and fat products. New Jersey: John Wiley \& Sons.

Stoskopf MK (1993) Fish Medicin. 1st ed. Philadelphia: W.B. Saunders.

Tietz NW (1986) Textbook of clinical chemistry. WB saunders, philadelphia, pp 1271- 1281.

Ullah N, Khan MA, Khan T, Asif AH, Ahmad W (2014). Mentha piperita in nephrotoxicity - a possible intervention to ameliorate renal derangements associated with gentamicin. Indian Journal of Pharmacology. 46(2):166170 . 
Vokovic-Gacic B, Simic D (1993). Identification of natural antimutagens with modulating effects on DNA repair. Basic Life Sciences, 61: 269-277.

Whyte SK (2007). The innate immune response of finfish--a review of current knowledge. Fish Shellfish Immunol 23: 1127-1151.

Yadegarinia D, Gachkar L, Rezaei MB, Taghizadeh M, Astaneh SA, Rasooli I
(2006). Biochemical activities of Iranian Mentha piperita L. and Myrtus communis L. essential oils. Phytochemistry 67(12):12491255 .

Young DS, Pestaner LC, Gibberman V (1975). Effects of drugs on clinical laboratory tests. Clin Chem., 21(5):1D-432D.

Zhang JT (2002). New drugs derived from medicinal plants. Therapie, 57, 137-150. 


\section{الملخص العربي \\ نشاط مزيج ثلاثي الأعشاب الطبية كمضاد للأكسدة ومحفز للمناعة والحماية الكلوية في القرموط الأفريقي}

ولاء فتحي عميش، زينب الأمجد و حسن أحمد

اكتسبت المكملات الغذائية العشبية الطبية قبولًا واسعًا في الإنتاج الحيو اني وقد تكون قابلة للنطبيق على أنظمة إنتاج نربية الأحياء المائية. تسنكثف الدر اسة الحالية التأثيرات البيولوجية لدمج المزيج العشبي من بذور الكمون الأسود (حبة البركة) ، والنعناع والثمر ، على

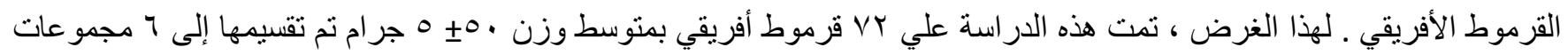
وتغذى على الوجبات الغذائية التجريبية لمدة 0؛ يوما متتالية. المجموعة الأولي ضابطة تم تغذيتها علي العليقة العادية بدون أي إضافات أما المجموعة الثانية تم تغذيتها علي العليقة العادية مضافا إليها ه. • من حبة البركة و أوراق النعناع والثمر وبعد انتهاء التجربة تم سحب عينات الدم للتحليل الييوكيميائي والمناعي وأخد الكبد والكلية والطحال لدراسة التغيرات النسيجية. المجموعات الأخرى تم استخدامها في حقن بكتريا فييريو فولنيكاس حيث انهنم حقن البكتريا مع المجموعة التي تتخذي علي العليقة العادية و المجموعة التي تتغذي علي العليقة العادية مضافا اليها مخلوط الأعثاب الثلاثة ومجموعة أخري تم حقنها بمحلول ملح و الأخيرة بدون حقن. أثبتت النتائج أن إجمالي قدرة مضادات الأكسدة ، ومستوي البروتين في الدم ، والألبومين و الجلوبيولينات لوحظت أنها أعلى بشكل ملحوظ في مجموعة الأسماك التي تتغذي علي مزيج الأعشاب مقارنة بالمجو عة الضابطة. زادت الخلايا الليمفاوية بنسبة كبيرة في مجموعة التغذية العشبية مقارنة بالمجموعة الضابطة بينما انخفضت نسبة الخلايا المتعادلة بشكل ملحوظ. على الرغم من أن مستوى اليوريا في الدم لم يتأثر بالمكملات العشبية ، فقد انخفض مستوى الكرياتينين في الدم بشكل ملحوظ كما أن معدل وزن الجسم من القرموط الأفريقي زادت بشكل

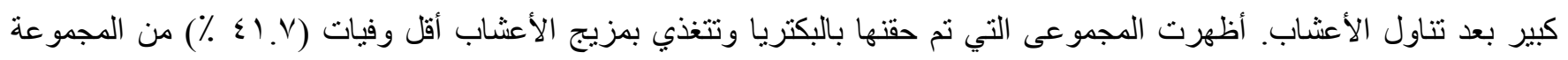
الضابطة. الأسمالك التي تلقت النظام الغذائي العثبي أظهرت بنية نسيجية طبيعية للكبد و الكلى والطحال. استنادا إلى النتائج الحالية جنبا إلى جنب مع انخفاض التكلفة ومضادات الأكسدة المحتملة والآثار المناعية من النباتات الطبية العثبية المختلطة المستخدمة في الدراسة ، فمن المستحسن أن تستخدم في تغذية الأسماك للحد من الخسائر التي تسببها بعض مسببات الأمر اض المائية. 